\title{
Schumpeterian patterns of innovation and the sources of breakthrough inventions: evidence from a data-set of $R \& D$ awards
}

\author{
Roberto Fontana · Alessandro Nuvolari · \\ Hiroshi Shimizu • Andrea Vezzulli
}

Published online: 15 July 2012

(C) Springer-Verlag 2012

\begin{abstract}
This paper examines the relationship between Schumpeterian patterns of innovation and the generation of breakthrough inventions. Our data source for breakthrough inventions is the "R\&D 100 awards" competition organized each year by the magazine Research \& Development. Since 1963, this magazine has been awarding this prize to 100 most technologically significant new products available for sale or licensing in the year preceding the judgment. We use USPTO patent data to measure the relevant dimensions of the technological regime prevailing in each sector and, on this basis, we provide a characterization of each sector in terms of the Schumpeter Mark I/Schumpeter Mark II archetypes. Our main finding is that breakthrough inventions are more likely to emerge in 'turbulent' Schumpeter Mark I type of contexts.
\end{abstract}

R. Fontana

University of Pavia, Via Ferrata 1, 27100 Pavia, Italy

R. Fontana $(\bowtie)$

KITeS - Bocconi University, Via Sarfatti 25, 20139 Milano, Italy

e-mail: roberto.fontana@unibocconi.it

A. Nuvolari

LEM - Sant'Anna School of Advanced Studies,

Piazza Martiri della Liberta' 33, 56172 Pisa, Italy

e-mail: alessandro.nuvolari@sssup.it

H. Shimizu

Institute of Innovation Research, Hitotsubashi University, Tokyo, Japan

e-mail: shimizu@iir.hit-u.ac.jp

\section{A. Vezzulli}

UECE-ISEG, Universitade Técnica de Lisboa,

Rua Miguel Lupi, 20, 1249-078 Lisboa, Portugal

e-mail: andreav@iseg.utl.pt 
Keywords Innovation patterns $\cdot$ Radical innovations •

Schumpeter Mark I and Mark II

JEL Classification $\mathrm{O} 31 \cdot \mathrm{O} 33$

\section{Introduction}

One of the robust findings emerging from the rich body of empirical research on innovation carried out over the last thirty years is that innovative activities differ across industries along several dimensions, such as the knowledge base underlying innovation processes, the type of actors and institutions involved in innovative activities, the characteristics and the economic effects of innovations (Malerba 2005). These differences have been highlighted both by detailed case studies of individual sectors (see, for example, the essays collected in Mowery and Nelson 1999) and by empirical contributions that have systematically compared quantitative measures of innovation with other economic characteristics of sectors (Cohen 2010).

In the evolutionary economics literature these differences in patterns of innovative activities across sectors have been captured by means of taxonomic exercises. The aim of these exercises was to identify in the welter of the empirical evidence some archetypical configurations capturing the keydimensions in which the structure of innovative activities differs systematically across sectors. Within this approach, one of the most common distinctions proposed to summarize the inter-sectoral differences in patterns of innovation is the characterization of industries in terms of Schumpeter Mark I and Schumpeter Mark II patterns. Schumpeter Mark I industries are characterized by turbulent environments with relatively low entry barriers, where innovations are (mostly) generated and developed by new 'entrepreneurial' firms. Accordingly, technological competition among firms in Schumpeter Mark I industries assumes the form of "creative destruction", with successful innovating entrants replacing incumbents. In contrast, Schumpeter Mark II industries are characterized by stable environments with relatively high entry barriers in which innovations are generated and developed by large established firms. In Schumpeter Mark II industries, technological competition assumes the form of "creative accumulation", with incumbent firms introducing innovations by mean of a process of consolidation of their technological capabilities along well established technological trajectories (Malerba 2005: 382). The terms Schumpeter Mark I and Mark II refer to the well-known distinction between the early view of innovation that Schumpeter advanced in The Theory of Economic Development (1911) ("Schumpeter Mark I") and the later view proposed by Schumpeter in Capitalism, Socialism and Democracy ("Schumpeter Mark II").

A substantial empirical literature has shown the existence of these two patterns of innovation as characteristic of many industrial sectors in different countries using data such as patents (Malerba and Orsenigo 1995, 1996) 
or responses to innovation surveys (Castellacci 2007). One relatively robust empirical finding is that Schumpeterian patterns of innovation are, by and large, technology-specific. More specifically, in different countries, the same industries display similar patterns of innovation (Malerba and Orsenigo 1996). Following this cue, most research efforts have tried to relate the two Schumpeterian patterns to a number of specific technological dimensions summarized by the concept of technological regime. A technological regime, as defined by Malerba and Orsenigo (1995, 1996, 1997), Breschi et al. (2000) is a synthetic description of the "framework conditions" (Castellacci 2007: 1111) in which innovative activities take place. These conditions shape the processes of variety generation and selection among the firms in the sector and, through this channel, they affect both the organization of innovative activities and the market structure of the industry. (Malerba and Orsenigo 1996, 1997) have proposed that the key dimensions of a technological regime are the level of technological opportunities, the degree of appropriability of innovations, the cumulativeness of technological advances and the characteristics of the knowledge base underlying innovative activities. In general, the evidence suggests that Schumpeter Mark I patterns of innovation emerge in the presence of high technological opportunities, low appropriability, and low cumulativeness. By contrast, high appropriability and high cumulativeness are conducive to the emergence of Schumpeter Mark II patterns. ${ }^{1}$

While most of the contributions in this field have studied the precise relationships between the dimensions of technological regimes and the sectoral patterns of innovative activities, the overall connection between technological regimes and the innovation performance of sectors have received much less attention. A notable exception is the recent contribution of Castellacci (2007) investigating the relationship between technological regimes and productivity growth.

In this paper, we focus on the relation between sectoral patterns of innovation and a more specific dimension of innovative performance, the generation of breakthrough inventions. This approach is somewhat reminiscent of the debate on the 'sources of invention' triggered by the contribution of Jewkes et al. (1958) who, on the basis of 70 case studies of breakthrough inventions, argued that, notwithstanding the emergence of corporate research laboratories, the most important inventions of the first half of the twentieth century had been actually generated by individual inventors and small companies. In other words, the ultimate source of truly significant inventions was outside the walls of the corporate research and development laboratories. For our purposes, we consider as breakthrough inventions the inventions that have won a prestigious competition organized by one of the leading magazines for R\&D practitioners. In comparison to other measures of innovative performance such as patents or productivity, this type of indicator seems to represent a more 'direct' measure

\footnotetext{
${ }^{1}$ Schumpeter Mark II patterns are, in principle, consistent both with low and high degrees of technological opportunities (Breschi et al. 2000: 395).
} 
of innovative performance. Furthermore, since in this paper we shall follow the common practice to use patent data to measure the relevant dimensions of the technological regimes, it seems useful to have a direct indicator of innovative performance at the sectoral level that is not also constructed using patents. The paper is structured as follows. Section 2 reviews the relevant background literature. Section 3 introduces our database. Section 4 presents the empirical results, and Section 5 concludes.

\section{Background literature}

\subsection{Technological regimes and Schumpeterian patterns of innovation}

In retrospect, some of the modern research on sectoral patterns of innovation emerged out of a feeling of dissatisfaction towards the 'mixed' evidence produced by the testing of the so-called 'Schumpeterian hypothesis' postulating a positive effect of firm size and market concentration on innovation. Following a suggestion of Nelson and Winter (1982), Malerba and Orsenigo (1995, 1996, 1997) argued that the inconclusive results of the literature studying the relationship between market structure and rates of innovation were due to a failure properly to acknowledge the specific conditions of technological opportunities and appropriability prevailing in each sector and, relatedly, to recognize that both innovation and market structure ought to be regarded as endogenous variables jointly determined by the nature of the prevailing technological regimes.

Malerba and Orsenigo's approach to this issue was to examine systematically sectoral patterns of innovation across countries using patent data. In general, they found that it was possible to use the Schumpeter Mark ISchumpeter Mark II distinction to characterize sectoral patterns of innovative activities in all the major industrialized countries. In particular, Malerba and Orsenigo (1995) examined patterns of innovation in different technology classes using USPTO patents over the period 1969-1986 for four European countries (Germany, France, UK and Italy), while Malerba and Orsenigo (1996) carried out a similar exercise using EPO patents over the period 19781991 for six major industrialized countries (USA, Germany, UK, France, Italy and Japan). The dimensions considered in the assessment of the patterns of innovation were: i) concentration and asymmetries among innovating firms in each sector (measured, respectively, by the $\mathrm{C} 4$ concentration ratio and the Herfindahl index computed using the shares of patents hold by different firms); ii) size of the innovating firms (measured as the total share of patents in the technology class belonging to firms with more than 500 employees); iii) changes over time in the hierarchy of innovators (measured using the Spearman correlation coefficient of the patents owned between the innovating firms in different periods); iv) relevance of the entry of new innovators (measured as the share of patents of firms applying for the first time in a specific technology class). 
Malerba and Orsenigo's findings showed that technology classes with low concentration and reduced asymmetries among innovating firms were characterized by the relatively small size of innovating firms, changes in the hierarchy of innovators and considerable innovators' entry, pointing towards a Schumpeter Mark I pattern. By contrast, technology classes with high concentration and asymmetries among innovating firms were characterized by the large size of innovators, a relative stability in the hierarchy of innovators, and limited entry, pointing towards a Schumpeter Mark II pattern. These results were further corroborated by a principal component analysis on the variables mentioned above. In all countries, the principal component analysis produced one dominant factor (explaining in all cases more than $50 \%$ of the variance) the loadings of which are fully consistent with the Schumpeter Mark I/Schumpeter Mark II distinction. The overall conclusion of these investigations was the recognition of systematic differences across industries in the patterns of innovation (differences that it is possible to characterize in terms of the Schumpeter Mark I and Schumpeter Mark II dichotomy) and of similarities across countries in sectoral patterns of innovation for a specific technology (Malerba and Orsenigo 1997: 94).

Malerba and Orsenigo's interpretive hypothesis of this finding is that the emergence of these two sectoral patterns of innovation is accounted for by different 'technological regimes' that shape and constrain innovative processes in different sectors. In their definition, a technological regime is a synthetic description of the technological environment in which firms act. More specifically, a technological regime is a specific combination of some basic characteristics of technologies: opportunity conditions, appropriability conditions, cumulativeness of technical progress, and the nature of the knowledge base (Malerba and Orsenigo 1997: 94). The hypothesis is that Schumpeter Mark I patterns of innovation emerge in contexts characterized by high technological opportunities, low appropriability and low cumulativeness, whereas Schumpeter Mark II pattern emerge in contexts of high appropriability and cumulativeness (technological opportunities can be both high or low). Breschi et al. (2000) provided a first (successful) test of these hypotheses concerning the relationship between technological regimes and sectoral patterns of innovation using data from the PACE innovation survey to measure the relevant dimensions of the technological regimes and EPO patents to measure the sectoral patterns of innovation.

Further contributions have confirmed the merits of introducing the Schumpeter Mark I/ Schumpeter Mark II distinction. ${ }^{2}$ Van Dijk (2000) studied the industrial structure and dynamics in Dutch manufacturing and found consistent differences in the patterns of industrial dynamics between Schumpeter

\footnotetext{
${ }^{2}$ Other contributions have, however, argued that the Schumpeter Mark I-Schumpeter Mark II distinction may be too narrow and does not map adequately the large empirical variety of intersectoral patterns of innovative activities. Therefore more articulated taxonomies of innovation patterns have been proposed. The most famous example is the Pavitt's taxonomy (Pavitt 1984). For a comprehensive discussion, see Marsili and Verspagen (2002).
} 
Mark I and Schumpeter Mark II industries. The distinction between Schumpeter Mark I and Schumpeter Mark II seems also useful to study patterns of innovation with broad technological fields. For example, Corrocher et al. (2007) have shown the existence of Schumpeter Mark I and Schumpeter Mark II patterns of innovation examining patents taken in different subsegments of ICT applications.

More recently, the focus of the empirical investigations has shifted towards the connection between technological regimes and innovation performance. Castellacci (2007) studied the relationship the relationship between differences in sectoral productivity growth and technological regimes in nine European countries (Germany, France, Italy, Netherlands, Norway, Portugal, Sweden, UK and Austria) in the period 1996-2001. Technological regimes are defined in terms of technological opportunities, appropriability and cumulativeness, and the measurement of the different dimensions of technological regimes is based on responses to the CIS surveys. Castellacci finds that Schumpeter Mark II sectors are characterized by higher rates of productivity growth. Furthermore, the relationship between the different characteristics of the technological regimes and productivity is different in the two Schumpeterian patterns.

\subsection{Schumpeterian patterns of innovation and breakthrough inventions}

Another critical dimension of technological performance is the emergence of breakthrough inventions. The recent emphasis on the key role of breakthrough inventions is related to the growing appreciation of the highly skewed nature of innovation size distributions (Silverberg and Verspagen 2007). Clearly, if the majority of innovations yield only modest returns and most economic value is actually generated by relatively few breakthrough inventions situated in the tail of the value distribution, the search for the possible determinants of these breakthrough inventions becomes a fundamental research issue (Scherer and Harhoff 2000).

Existing approaches to the study of the role of breakthrough invention can be classified into two camps. On the one hand, there are historians of technology and economic historians who have frequently acknowledged that serendipity plays a large role in the generation of breakthrough inventions. Mokyr (1990: 13) is possibly summarizing what is the conventional wisdom on this issue when he writes: "macro-inventions [...] do not seem to obey obvious laws, do not necessarily respond to incentives and defy most attempts to relate them to exogenous economic variables. Many of them resulted from strokes of genius, luck or serendipity. Technological history, therefore, retains an unexplained component that defies explanation in purely economic terms. In other words, luck and inspiration mattered, and thus individuals made a difference". Still, some economic historians have been able to unravel some significant relationship between breakthrough inventions and economic and social variables (Khan and Sokoloff 1993). 
On the other hand, there is the recent literature in management. Ahuia and Lampert (2001) assess the relationship between breakthrough inventions and R\&D strategies at firm level. Their findings suggest that established firms tapping new technologies are more likely to introduce breakthrough inventions. Chandy and Tellis (2000) look at the role of incumbent firms in the generation of radical innovations. They find that, despite their inertia, established firms can be an important source of radical innovations. Finally, Schoenmakers and Duysters (2010) analyze the connection between breakthrough inventions and different types of knowledge. They find that radical inventions are to a higher degree based on existing knowledge rather than incremental inventions. They also find that inter-firms collaborations play an important role in the development of radical inventions, as highlighted also by Singh and Fleming (2010) at the individual inventor level.

This paper contributes to this emerging literature on the sources of breakthrough inventions by examining this issue from the perspective of the literature on Schumpeterian patterns of innovation. More specifically, we shall not deal directly with the issue of the possible economic and social determinants of major macro-inventions, but we shall limit ourselves to study the possible role played by different Schumpeterian patterns of innovation in the generation of breakthrough inventions. If it turns out that Schumpeterian patterns affect the generation of breakthrough inventions, it is important that future contributions devoted to study of the sources of breakthrough inventions at micro level will try to control explicitly for the dimensions of the technological regime prevailing in the industries under consideration. A similar exercise was carried out by Granstrand and Alange (1995) for the Swedish case using a sample of 100 'significant' inventions that occurred in the period 1945-1980, although their focus was not so much on the impact of the technological regimes but on the relative contribution of different organizational structures (individual inventors, small firms, large firms) to the generation of inventive breakthroughs. Their findings were mixed. They found that large firms were responsible for $80 \%$ of the inventions in their sample, but still a sizable share of breakthrough inventions (i.e. the remaining $20 \%$ ) could be ascribed to individual inventors and small firms.

\section{The "R\&D 100" awards database}

Our source of data is the 'R\&D 100 Awards' competition organized by the magazine Research and Development (previously called Industrial Research). The magazine, founded in 1959, is one of the most authoritative regular publications for R\&D practitioners. ${ }^{3}$ The 'R\&D 100 Awards' competition has been

\footnotetext{
${ }^{3}$ The information reported here on $R \& D$ magazine and the $R \& D$ competition was retrieved from http://www.rdmag.com, last accessed on 7/7/2011.
} 
running continuously since 1963 . Each year the magazine awards with a prize the 100 most technologically significant products available for sale or licensing in the year preceding the judgment.

Throughout the years, breakthroughs inventions such as Polacolor film (1963), the flashcube (1965), the automated teller machine (1973), the halogen lamp (1974), the fax machine (1975), the liquid crystal display (1980), the printer (1986), the Kodak Photo CD (1991), the Nicoderm antismoking patch (1992) and Taxol anticancer drug (1993) have received the prize. In order to apply for the prize, the inventors or their companies must fill out an application form providing a detailed description of the invention. The prize consists of a plaque which is presented at a special ceremony. There is no monetary prize. The prize is awarded by a jury composed of university professors, industrial researchers and consultants with a certified level of competence in the areas they are called upon to asses. Jury members are selected by the editor of the magazine and inventions are assessed according to two criteria: i) technological significance (i.e., whether the product can be considered a major breakthrough from a technical point of view) and ii) competitive significance (i.e., how the performance of the product compares to rival solutions available on the market). R\&D 100 awards are accolades comparable to the Oscars for the motion picture industry as "they carry considerable prestige within the community of R\&D professionals" (Block and Keller 2009: 464).

There are a number of characteristics of the R\&D 100 awards competition that, prima facie, appear particularly promising for the study of inventive breakthroughs. First, the R\&D 100 awards competition represents a good opportunity for companies, and government laboratories to showcase their inventions. Second, R\&D 100 awards are granted to inventions that, at least in principle, should embody a clearly documented improvement of the state-ofthe-art (i.e. a technological breakthrough). Third, the selection of the awards is made by a competent, authoritative jury of experts. Fourth, $R \& D$ awards may be assigned both to patented and not-patented inventions. Finally, there seems to be limited space for strategic behaviors and attempts to conditioning the jury, because the nature of the prize is simply honorific.

Given these properties, it is surprising that economists of innovation have so far paid scant attention to this type of data. To the best of our knowledge, the R\&D 100 awards data have been so far only used in three contributions: Carpenter et al. (1981), Scherer (1989) and, more recently, Block and Keller (2009). Carpenter et al. (1981) used these data to study differences in citations received between patents covering awarded inventions and a random sample of patents, providing an important corroboration for the use of forward citations as an indicator of patent quality. Scherer (1989) used information on the mean and maximum R\&D costs of the awarded inventions to study the distribution of R\&D investments. Finally, Block and Keller (2009) used the R\&D 100 awards to gain insights on the growing importance of public institutions in the US innovation system over the period 1971-2006. From our perspective, it is reassuring that three authoritative contributions in the field of 
innovation studies have employed the data to study the nature of breakthrough inventions.

\section{Empirical analysis}

Retrieving the information from different issues the magazine, we have constructed a dataset with all the R\&D 100 awards granted from 1963 to 2005. In this section we use the dataset to study the impact of different Schumpeterian regimes on the generation of breakthrough inventions. We proceed in two steps. First, we introduce some preliminary descriptive statistics of the dataset to check the reliability of the source. Second, we carry out an econometric study of the probability of the occurrence of breakthrough invention as a function of the Schumpeterian regime prevailing at the sectoral level.

\subsection{Descriptive statistics}

Figure 1 displays the share of awards granted to US applicants for the prize. The nationality of the applicants has been assigned using the organization, rather than by looking at the nationality of the inventors. Over the period 1963-2002, the share of US awards declined indicating that other countries closed the gap with the US in terms of technological performance. Interestingly enough, during the period 2003-2005, the US recovered their edge, but, of course, this is a too short span of time for detecting clear trends.

Figure 2 displays the share of awards received by applicants from different countries by sub-periods excluding the US that, as one would have expected given the nature of the competition and the place of publication of the magazine, dominate the sample. The figures clearly indicate that Japan and Germany are the two most prominent contenders of US technological leadership. Figure 2 shows how this effort of closing the gap evolved over time, with

Fig. 1 Share of "R\&D 100 "awards received by US applicants

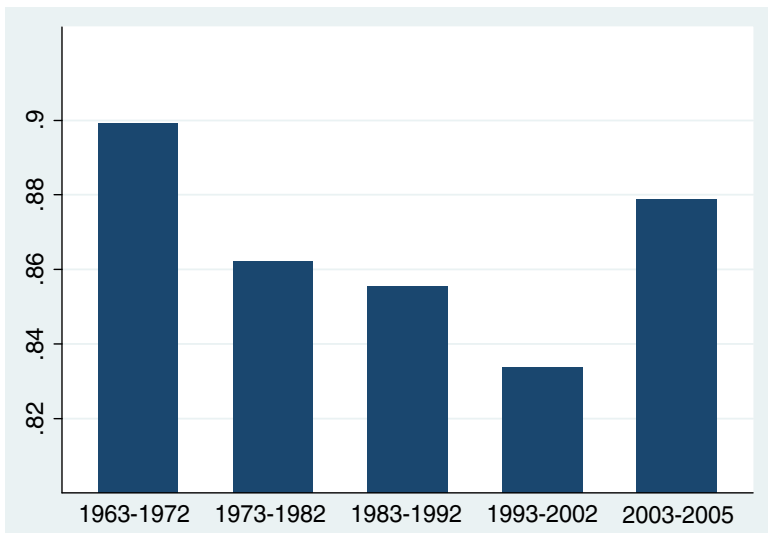




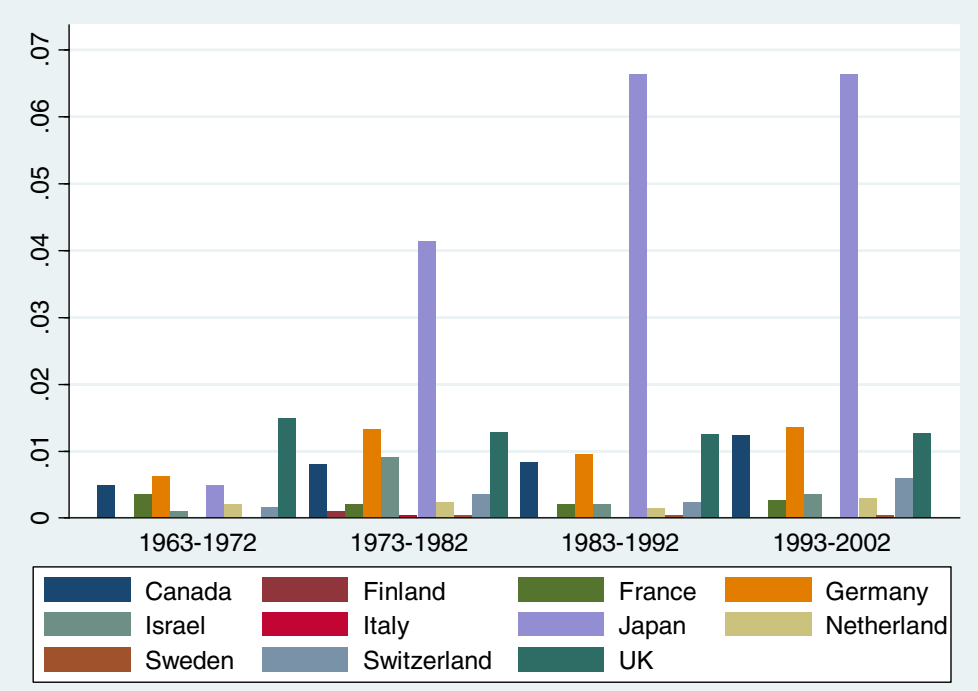

Fig. 2 Share of "R\&D 100" awards received by applicants of different countries

Japan and Germany progressively overtaking two older established players, France, and UK.

Figure 3 shows the shares of awards granted to different type of organizations. The trends here are consistent with the literature that has recently

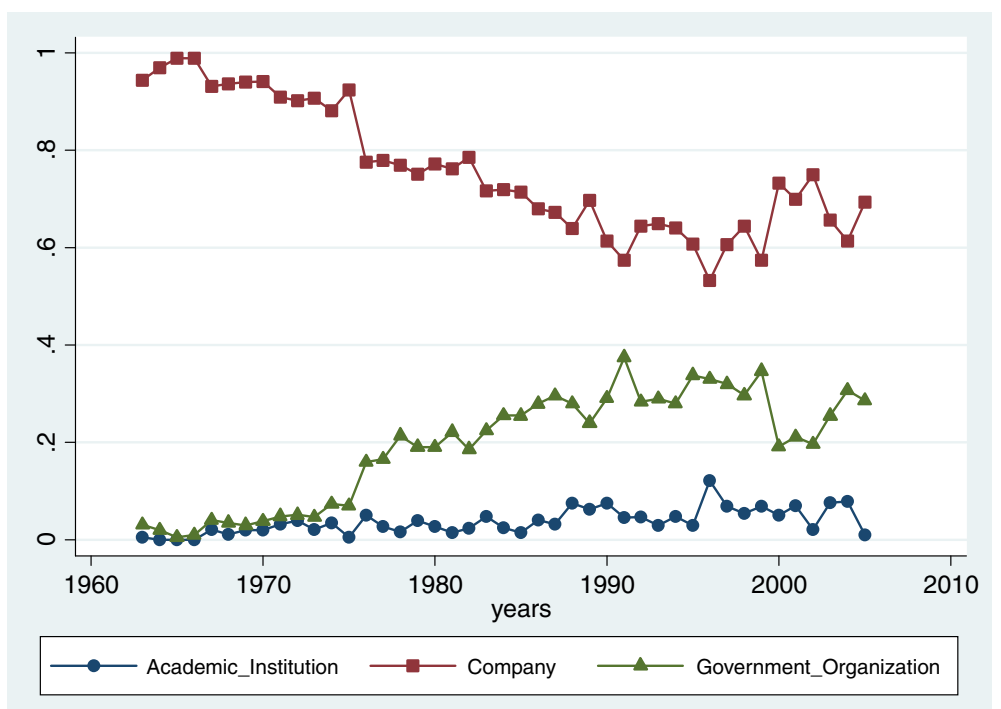

Fig. 3 Shares of "R\&D 100" awards granted to different type of organization 


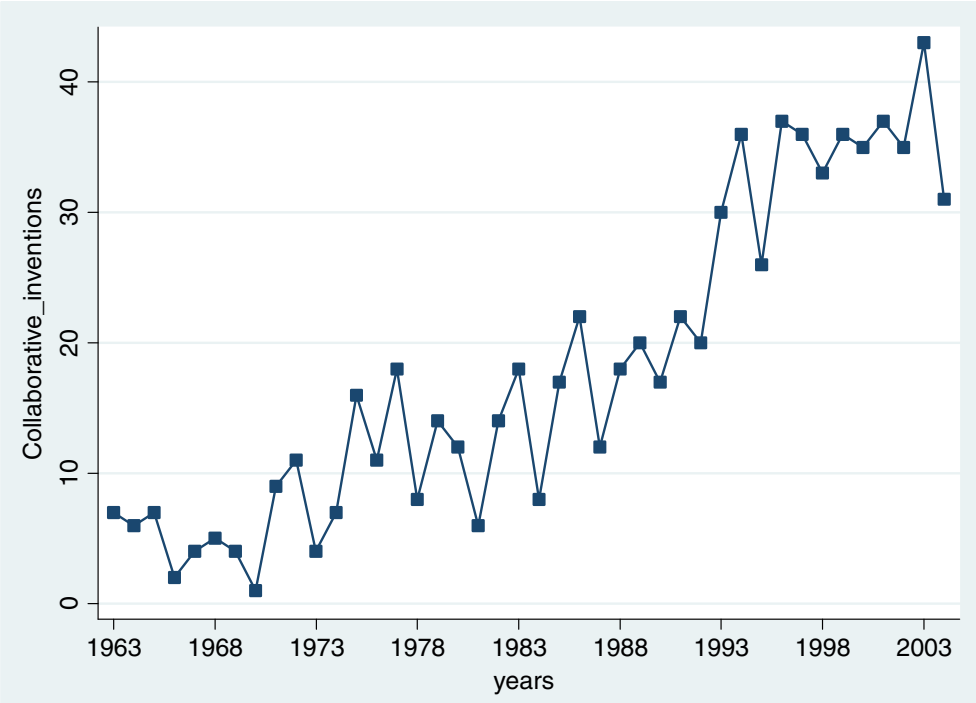

Fig. 4 Number of collaborative inventions receiving an "R\&D 100" award

pointed out the increasing involvement in inventive activities of a number of new actors such as government laboratories and universities. Whereas in the early 1960s, corporations were the primary source of inventions, in the most recent years this has clearly not been the case.

Figure 4 displays the number of awards that are the outcome of collaborative activities. The figure shows an increasing trend which is fully consistent with the emphasis that has been put on the growing role of cooperation and networking in the field of innovative activities (Freeman 1991).

To carry out our analysis at the sectoral level, we classified each awarded invention according to a technology-oriented classification of 30 different sectors based on the co-occurrence of the International Patent Classification (IPC) codes proposed by the Observatoire des Sciences et des Techniques (OST). ${ }^{4} \mathrm{We}$ assigned each R\&D 100 invention to only one of the 30 OST sectors. These sectors were further aggregated into 5 'macro' technological classes (called 'OST5' henceforth) defined according to the ISI-INIPI-OST patent classification based on the EPO IPC technological classes, as reported in Table $1 .^{5}$

Figure 5 contains histograms showing the distribution of the awarded inventions across the 30 OST sectors.

\footnotetext{
${ }^{4}$ See Hinze et al. (1997).

${ }^{5}$ Technology-oriented classification system jointly elaborated by the German Fraunhofer Institute of Systems and Innovation Research (ISI), the French Patent Office (INIPI) and the Observatoire des Science and des Techniques (OST).
} 
Table 1 Aggregation of the 30 ISI-INPI-OST sectors in 5 macro-classes

\begin{tabular}{lll}
\hline MacroISI-INIPI-OST & ISI-INIPI-OST & Technological class \\
\hline 1 & $1,2,3,4,5$ & Electrical engineering \\
2 & $6,7,8,27$ & Instruments \\
3 & $9,10,11,12,14,15$ & Chemistry \& pharmaceuticals \\
4 & $13,16,17,18,20,24,25$ & Process engineering \\
5 & $19,21,22,23,26,28,29,30$ & Mechanical engineering \\
\hline
\end{tabular}

As one would have expected, there is some distortion towards 'high-tech' sectors such as instruments, biotechnology, information and communication technologies, optics (lasers), and semiconductors. The predominant sector is instrumentation (control instruments). On the one hand, this may be clearly explained by the interests of the editors and the readership of the magazine, given that instrumentation plays a central role in the majority of modern R\&D processes. On the other hand, this may be the consequence of the fact that it is easier for inventions in these categories to prove that they are superior to the state of the art by means of quantitative assessment of technological performance. All in all, these results confirm that the R\&D 100 awards tend to cover, as one would have expected, a high-tech R\&D intensive segment of the economy.

Finally, we check whether the R\&D 100 inventions that were patented (more specifically, those for which we were able to match with one USPTO patent) receive more citations than an analogous random sample of patents. Accordingly, for each R\&D invention with a USPTO patent we construct a

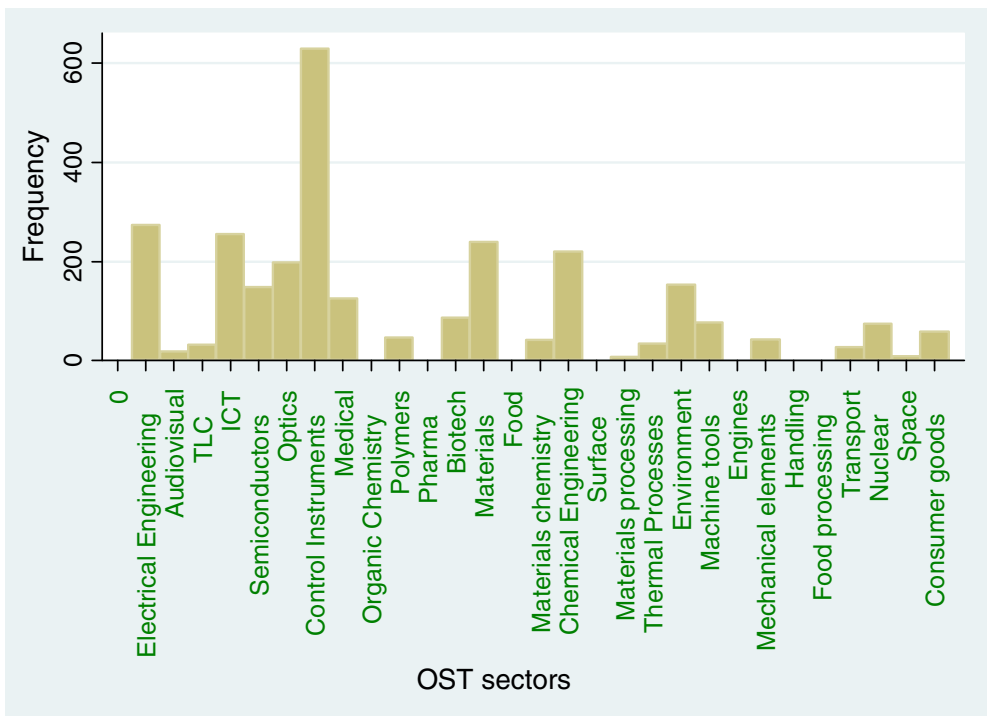

Fig. 5 Distribution of "R\&D 100" awards across technology classes, 1963-2005 
Table 2 Patent citations received by R\&D 100 inventions and a random sample of patents (matched by granted year and technology class)

\begin{tabular}{lcclllr}
\hline & Number & Mean & Median & $\begin{array}{l}\text { Standard } \\
\text { deviation }\end{array}$ & Min & Max \\
\hline R\&D 100 patents & 535 & 12.88037 & 7 & 16.17822 & 0 & 137 \\
Random Sample & 5331 & 8.483024 & 4 & 14.11133 & 0 & 329 \\
\hline
\end{tabular}

Mann-Whitney test rejects the null hypothesis of equal populations

'matched random' sample of ten patents from the same grant year and from the same IPC class. The results of this test are reported in Table $2 .{ }^{6}$ The non parametric Mann-Whitney test confirms that the median number of citations of patents associated with a R\&D 100 invention is significantly higher than the median of the random matched sample. These results confirm the early findings of Carpenter et al. (1981) obtained for the two years 1969-1970 of awards and provides an important corroboration for our use of the R\&D 100 data set as an indicator of breakthrough inventions.

\subsection{The econometric exercise}

In this section, we carry out our econometric exercise. Our main explanatory variables are constituted by a set of time-varying indicators constructed using patent based data for each of the five macro-classes mentioned above. These indicators aim at capturing different patterns of innovative activities across classes and over time. ${ }^{7}$ Following the contributions of Breschi et al. (2000), Hall et al. (2001) and Corrocher et al. (2007), we computed the indicators as follows (where $j=1, \ldots, 5$ for each OST5 sector and $t=1976, \ldots, 2006$ is the year of granting of each patent):

1) $P A T_{G R O W T H_{j t}}=\frac{p a t_{t i t}-p a t_{j t-1}}{p a t_{i t-1}}$

where pat $_{j t}$ is the total number of patents granted in OST5 class $j$ in year $t$.

2) Entry $_{j t}=\frac{\text { newpat }_{j t}}{\text { pat }_{j t}}$

where newpat $_{j t}$ is the total number of patents granted in OST5 class $j$ in year $t$ by new innovators (i.e. by firms patenting for the first time in class $j$ ).

\footnotetext{
${ }^{6}$ The random matched sample includes 5331 patents and not 5350 because, for some specific years in some technology classes, it was not possible to collect enough patents to create the match.

${ }^{7}$ Our main source of information is the NBER Patent Data Project which collects a very comprehensive set of information on USPTO patents for the 1976-2006 period (e.g. dates of application and grant, inventors and applicant's name, number of claims, technological classes, forward and backward citations, etc.). The reclassification of all USPTO patents according to the 2008 IPC classification system is available on the NBER Patent Data Project website and it has been performed on the basis of the International Patent Classification Eighth Edition available at: http://www.uspto.gov/go/classification/uspc002/us002toipc8.htm. For a comprehensive description of the database, see Hall et al. (2001).
} 


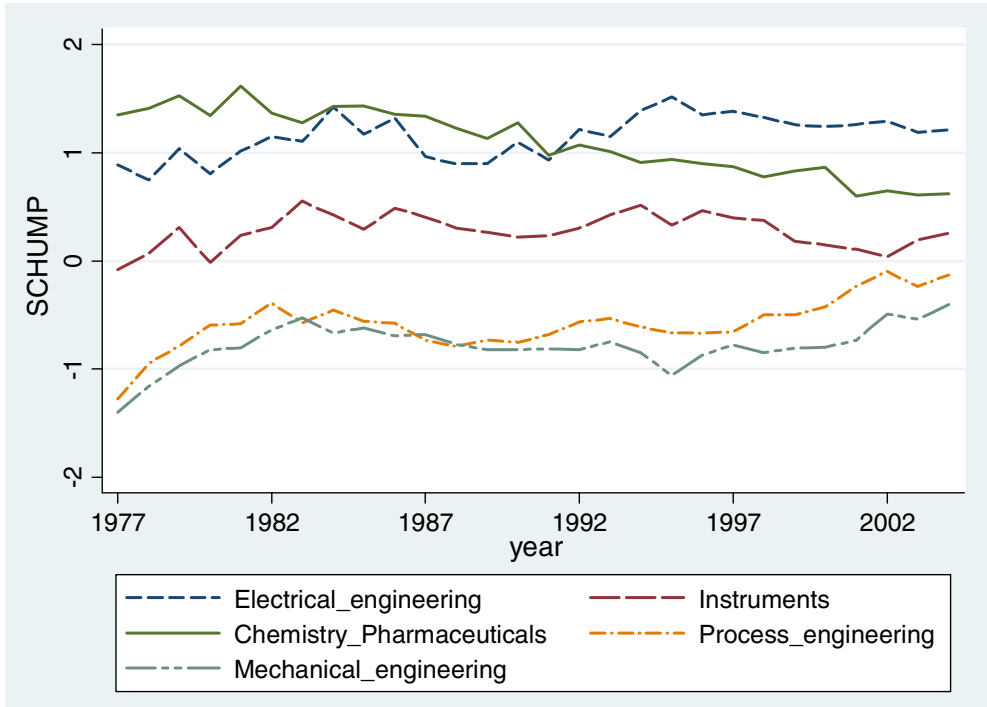

Fig. 6 The dynamics of SCHUMP for each OST5 macro sector (1977-2005)

3) $C 4_{j t}$ representing the concentration ratio of the top four patenting firms (in terms of number of patents granted in a given year $t$ and class $j$ ).

4) Stability $_{j t}$ is the Spearman rank correlation coefficient between hierarchies (in term of number of patents granted) of firms patenting in year $t$ and firms patenting in year $t-1$ in class $j$.

Following Breschi et al. (2000), the last three indicators (Entry, C4 and Stability) are consolidated in a unique indicator called Schump $p_{j t}$ by means of principal component analysis. Schump $p_{j t}$ is our main variable of interest and represents the prediction obtained using the scoring coefficients of the first component and the standardized values of the original variables. ${ }^{8}$ It provides an indication of the type of Schumpeterian pattern of innovation prevailing in a given class $i$ in year $t$. High values of $S_{c h u m p}$ indicate a Schumpeter Mark II type regime (i.e., a "deepening" pattern of innovative activities with a concentrated and stable population of innovators). Low values of Schump indicate a Schumpeter Mark I type regime (i.e., a "widening" pattern with a large and turbulent population of innovators) (Breschi et al. 2000). Figure 6 depicts the different trend of Schump ${ }_{j t}$ across the OST5 macro sectors within our time window.

Two sectors (Electrical Engineering and Chemistry \& Pharmaceuticals) are consistently close to a Schumpeter Mark II type of pattern, while two

\footnotetext{
${ }^{8}$ The extracted principal component accounts for about $70 \%$ of the total variance. The correlations between the principal component and our three original indicators C4, Entry, and Stability are $0.37,-0.67$ and 0.64 , respectively.
} 
other sectors (Mechanical and Process Engineering) are close to a Schumpeter Mark I type of pattern and one sector (Instruments) displays an intermediate pattern between these two.

5) Herfsources tech $_{\text {it }}$ is an index of the relative variety of knowledge sources across technological classes and is calculated in a similar way as in Corrocher et al. (2007). Let $a_{j h t}=\frac{c_{j h t}}{c_{i t}}$ be the share of backward citations from patents granted in year $t$ and belonging to OST5 class $j$ to previous patents in IPC class $h$ (defined at 4 digit level), where $c_{j h t}$ is the total number of patents belonging to IPC class $h$ and cited by patents granted in year $t$ and belonging to OST5 class $j$ and $c_{j t}=\sum_{h} c_{j h t}$.

Let then $v_{j h t}=\frac{p_{j h t}}{p_{j t}}$ be the share of patents (for each granting year $t$ ) in OST5 class $j$ belonging to IPC class $h$. Let Herf tech $_{j t}$ and Herfcit tech $_{j t}$ be the corrected Herfindahl indexes (Hall et al. 2001) calculated using, respectively, the shares $c_{j h t}$ and $v_{j h t}$ and indicating how much each OST5 class $j$ and its knowledge sources are concentrated (in term of number of patents granted and number of backward citations made) across different IPC 4 digit sub-classes in a given year $t$. The resulting relative index of concentration of knowledge sources across IPC technological classes is given by the ratio of the previous two indexes: Herfsources tech $_{j t}=\frac{\text { Herfcit }_{\text {tech }_{\text {it }}}}{\text { Herf }_{\text {tech }_{j t}}}$.

6) Herfsources $_{\text {firm }_{j t}}=\frac{\text { Herficit }_{\text {fimm }_{j t}}}{\text { Herffirm }_{j t}}$. This is an index of the relative variety of knowledge sources across firms and is calculated (for each granting year $\mathrm{t}$ ) in a similar way as Herfsources tech $_{j i}$. Here the Herfindahl index at the numerator is calculated using the shares of backward citations from patents in class $\mathrm{j}$ to patents applied by firm z: $b_{j z t}=\frac{d_{j z t}}{d_{j t}}$, where $d_{j z t}$ is the total number of cited patents from OST5 class $j$ applied by firm $z$ (excluding self citations) and $d_{j t}=\sum_{z} d_{j z t}$. The Herfindahl index at the denominator measures the degree of concentration across firms in a given class $\mathrm{j}$ calculated with respect to the number of patents granted in a given year $\mathrm{t}$.

7) Selfsources $_{j t}=\frac{s c_{j t}}{c_{i t}}$ is an index of intensity of internal knowledge sources and is defined for each OST5 class $j$ and granting year $t$ as the ratio between the total number of self-citations (i.e. backward citations to patents applied by the same firm z) over the total number of backward citations.

In addition to these indicators we also include 'applicant level' variables and further controls. Our final reference period of analysis ranges from 1977 to 2005 with a total of 2802 inventions awarded. ${ }^{9}$ Table 3 gives a comprehensive overview of the variables used in the econometric exercise.

\footnotetext{
${ }^{9}$ We dropped the first (1976) and last (2005) year of reference to avoid possible inconsistencies when calculating our time-varying industry indicators based on patent data.
} 
Table 3 Description of the variables

\begin{tabular}{|c|c|c|}
\hline & Description & Type \\
\hline \multicolumn{3}{|l|}{ Dependent variable } \\
\hline OST5 & $\begin{array}{l}\text { Invention-type classification according } \\
\text { to OST5 (see Table } 1)\end{array}$ & $\begin{array}{l}5 \text { categories: } \\
\quad j=1,2,3,4,5 \text {. }\end{array}$ \\
\hline \multicolumn{3}{|l|}{ Independent variables } \\
\hline Sector-level characteristics & $\begin{array}{l}\mathrm{j}=\text { category of the invention (OST5); } \\
\mathrm{t}=\text { year of award }\end{array}$ & \\
\hline PAT_GROWTH $_{\text {jt }}$ & Patent growth rate & Continuous \\
\hline SCHUMP $_{\mathrm{jt}}$ & $\begin{array}{l}\text { Schumpeterian pattern of innovative } \\
\text { activities index }\end{array}$ & Continuous \\
\hline HERFSOURCES_TECH $_{\mathrm{jt}}$ & $\begin{array}{l}\text { Variety of knowledge sources across } \\
\text { technological classes index }\end{array}$ & Continuous \\
\hline HERFSOURCES_FIRM $_{\text {jt }}$ & $\begin{array}{l}\text { Variety of knowledge sources across } \\
\text { firms index }\end{array}$ & Continuous \\
\hline SELFSOURCES $_{\mathrm{jt}}$ & $\begin{array}{l}\text { Intensity of internal knowledge } \\
\text { sources index }\end{array}$ & Continuous \\
\hline \multicolumn{3}{|l|}{ Invention-level characteristics } \\
\hline MAPPL & $\begin{array}{l}=1 \text { for multiple applicant organizations, } \\
=0 \text { otherwise }\end{array}$ & Dummy \\
\hline NINV & Number of inventors & Count \\
\hline USA & $\begin{array}{l}=1 \text { if at least one applicant is a U.S. } \\
\text { organization, }=0 \text { otherwise }\end{array}$ & Dummy \\
\hline GOV & $\begin{array}{l}=1 \text { if at least one applicant is a } \\
\text { governmental organization, } \\
=0 \text { otherwise }\end{array}$ & Dummy \\
\hline ACAD & $\begin{array}{l}=1 \text { if at least one applicant is an academic } \\
\text { organization, }=0 \text { otherwise }\end{array}$ & Dummy \\
\hline \multicolumn{3}{|l|}{ Other controls } \\
\hline dum1986_1995 & $\begin{array}{l}=1 \text { the invention has been awarded in the } \\
1986-1995 \text { decade, }=0 \text { otherwise }\end{array}$ & Dummy \\
\hline dum1996_2005 & $\begin{array}{l}=1 \text { the invention has been awarded in the } \\
1996-2005 \text { decade },=0 \text { otherwise }\end{array}$ & Dummy \\
\hline
\end{tabular}

Tables 4 and 5 report the main descriptive statistics of the variables used in the analysis, as well as the distribution of the awarded inventions across sectors and over time.

Table 4 Descriptive statistics

\begin{tabular}{llllll}
\hline Variable & Obs & Mean & Std. dev. & Min & Max \\
\hline OST5 & 2802 & 2.514 & 1.322 & 1 & 5 \\
PAT_GROWTH $_{\text {jt }}$ & 2802 & 0.049 & 0.126 & -0.290 & 0.478 \\
SCHUMP $_{\text {jt }}$ & 2802 & 0.261 & 0.733 & -1.412 & 1.602 \\
HERFSOURCES_TECH $_{\text {jt }}$ & 2802 & 0.521 & 0.103 & 0.273 & 0.910 \\
HERFSOURCES_FIRM $_{\mathrm{jt}}$ & 2802 & 0.841 & 0.156 & 0.565 & 1.382 \\
SELFSOURCES $_{\mathrm{jt}}$ & 2802 & 0.142 & 0.048 & 0.085 & 0.448 \\
MAPPL & 2802 & 0.256 & 0.437 & 0 & 1 \\
NINV & 2802 & 1.665 & 0.902 & 1 & 5 \\
USA & 2802 & 0.877 & 0.329 & 0 & 1 \\
GOV & 2802 & 0.320 & 0.467 & 0 & 1 \\
ACAD & 2802 & 0.074 & 0.262 & 0 & 1 \\
dum1986_1995 & 2802 & 0 & 0 & 0 & 1 \\
dum1996_2005 & 2802 & 0.322 & 0.467 & 0 & 1 \\
\hline
\end{tabular}




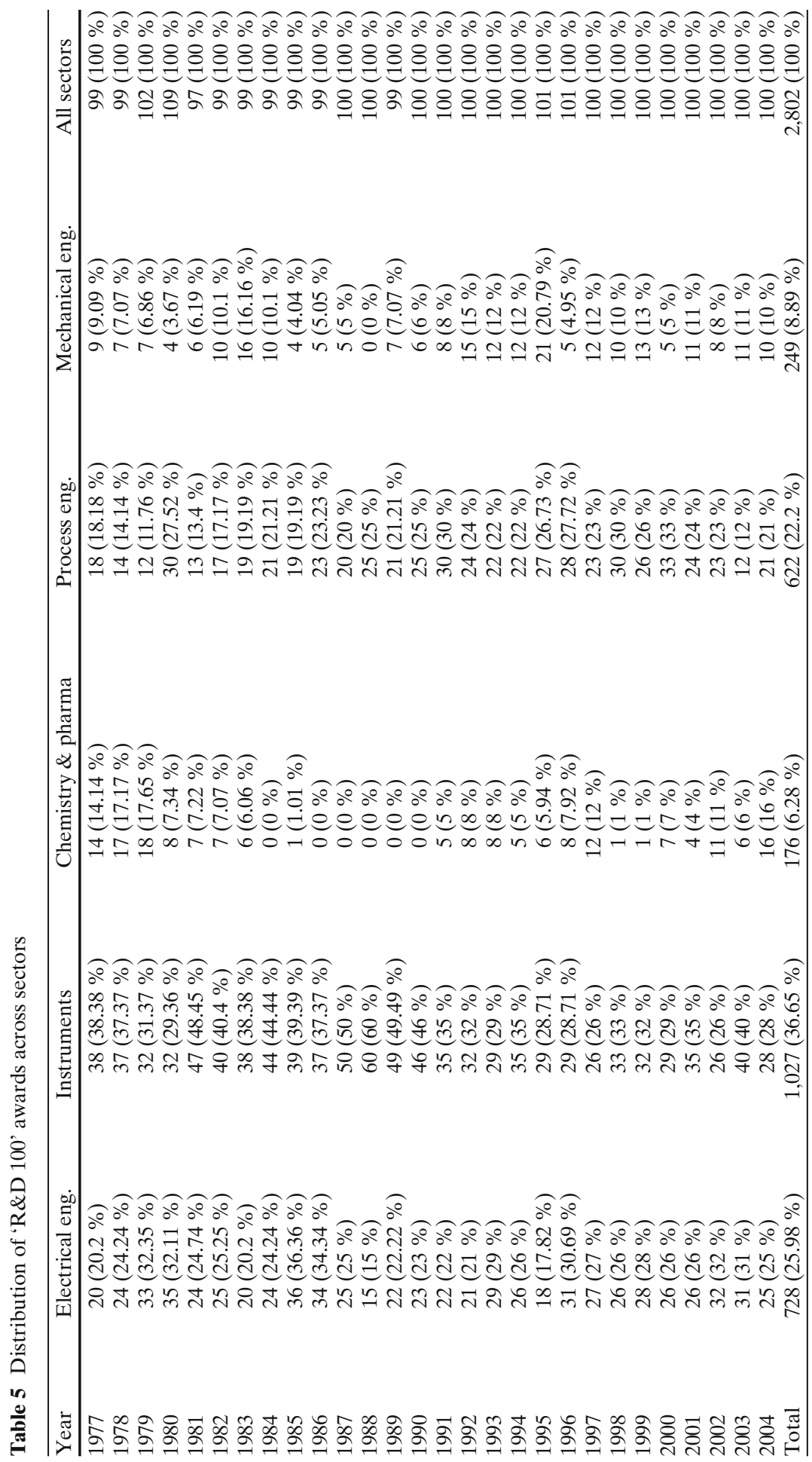


In our first model, we analyze the factors affecting the probability of observing a breakthrough invention in each OST5 sector by considering both industry-level technological regimes and invention specific characteristics. Even though in our setting this probability does not obviously reflect directly the specific choice made by an individual amongst a fixed set of alternatives maximizing a latent utility function, we can assume that the observed distribution of prizes across sectors (as resulting by the yearly decision of the awarding board) would mimic quite closely how 'nature' chooses in which sectors a breakthrough invention is more likely to occur.

We, therefore, rely on the estimation of a Conditional Multinomial Logit (CML) model with both alternative-varying and individual-varying covariates. In this setting, the probability of observing a breakthrough invention $i$ in a given macro-sector $j$ is defined as:

$$
p r_{i j}=\frac{\exp \left(X_{i j} \beta+Z_{i} \gamma_{i}\right)}{\sum_{i=1}^{m} \exp \left(X_{i j} \beta+Z_{i} \gamma_{i}\right)}
$$

where $X_{i j}$ are a set of alternative-specific and $Z_{i}$ are a set of case-specific covariates, respectively. Table 6 reports the estimated coefficients for the model.

The marginal effects for individual-specific covariates are computed as follows:

$$
\frac{\partial p r_{i j}}{\partial Z_{i}}=p r_{i j}\left(\gamma_{j}-\bar{\gamma}_{t}\right)
$$

where $\bar{\gamma}_{t}$ is a probability weighted average of the estimated coefficients. The marginal effect for a given alternative-specific covariate $x_{r i k}$ (i.e. the value of the covariate $x_{r}$ for individual $i$ and alternative $k$ ) is computed as:

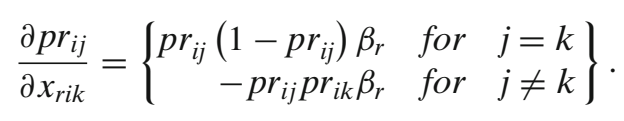

Thus the own-marginal effect (for $j=k$ ) has the same sign of the estimated coefficient, whereas the cross-marginal effect (for $j \neq k$ ) has the opposite sign.

In Table 7 below, we report only individual-specific and own alternativespecific marginal effects. For each alternative, they are computed at the average value of each covariate.

Collaboration (i.e. having a multiple applicant) (MAPPL) decreases the probability of observing a breakthrough invention in the sector of Instruments $(-0.073)$, whereas it increases the probability of observing a breakthrough invention in the sector of Mechanical Engineering (+0.087). Breakthrough inventions with at least one U.S applicant organization are more likely to occur in the Chemistry \& Pharmaceuticals and Process Engineering sectors, whereas they are less likely to occur in the Electrical Engineering sector. The presence of at least one governmental applicant decreases the probability of observing a 
Table 6 Conditional Multinomial Logit regressions

\begin{tabular}{|c|c|c|c|c|c|}
\hline Variables & $\begin{array}{l}(1) \\
\text { All } \\
\text { sectors }\end{array}$ & $\begin{array}{l}\text { (2) } \\
\text { Instruments }\end{array}$ & $\begin{array}{l}\text { (3) } \\
\text { Chemistry } \\
\text { pharma }\end{array}$ & $\begin{array}{l}4) \\
\text { Process } \\
\text { eng. }\end{array}$ & $\begin{array}{l}(5) \\
\text { Mechanical } \\
\text { eng. }\end{array}$ \\
\hline MAPPL & & $\begin{array}{l}-0.237^{*} \\
(0.130)\end{array}$ & $\begin{array}{r}-0.349 \\
(0.242)\end{array}$ & $\begin{array}{c}0.0453 \\
(0.138)\end{array}$ & $\begin{array}{r}0.605 * * * \\
(0.174)\end{array}$ \\
\hline NINV & & $\begin{array}{l}0.0682 \\
(0.0583)\end{array}$ & $\begin{array}{c}0.185^{* *} \\
(0.0910)\end{array}$ & $\begin{array}{l}0.132 * * \\
\quad(0.0627)\end{array}$ & $\begin{array}{l}0.0366 \\
(0.0829)\end{array}$ \\
\hline USA & & $\begin{array}{r}0.380 * * * \\
(0.145)\end{array}$ & $\begin{array}{r}0.918 * * * \\
(0.294)\end{array}$ & $\begin{array}{r}0.848 * * * \\
(0.186)\end{array}$ & $\begin{array}{l}0.254 \\
(0.215)\end{array}$ \\
\hline GOV & & $\begin{array}{r}-0.124 \\
(0.113)\end{array}$ & $\begin{array}{r}-0.567 * * * \\
(0.212)\end{array}$ & $\begin{array}{r}-0.0606 \\
(0.124)\end{array}$ & $\begin{array}{r}-0.388 * * \\
(0.172)\end{array}$ \\
\hline ACAD & & $\begin{array}{r}0.486 * * \\
(0.201)\end{array}$ & $\begin{array}{l}0.319 \\
(0.333)\end{array}$ & $\begin{array}{r}-0.455^{*} \\
(0.247)\end{array}$ & $\begin{array}{r}-0.846 * * \\
(0.355)\end{array}$ \\
\hline dum1986_1995 & & $\begin{array}{r}-0.0995 \\
(0.152)\end{array}$ & $\begin{array}{r}-0.595 * * \\
(0.246)\end{array}$ & $\begin{array}{l}0.196 \\
(0.164)\end{array}$ & $\begin{array}{r}-0.114 \\
(0.226)\end{array}$ \\
\hline dum1996_2005 & & $\begin{array}{r}-0.416^{* * *} \\
(0.146)\end{array}$ & $\begin{array}{l}0.340 \\
(0.311)\end{array}$ & $\begin{array}{r}-0.0359 \\
(0.181)\end{array}$ & $\begin{array}{r}-0.348 \\
\quad(0.260)\end{array}$ \\
\hline PAT_GROWTH & $\begin{array}{l}0.603 \\
\quad(0.509)\end{array}$ & & & & \\
\hline SCHUMP & $\begin{array}{r}-0.481 * * * \\
(0.178)\end{array}$ & & & & \\
\hline HERFSOURCES_TECH & $\begin{array}{r}-0.676 \\
(1.084)\end{array}$ & & & & \\
\hline HERFSOURCES_FIRM & $\begin{array}{r}-1.106^{* * * *} \\
(0.325)\end{array}$ & & & & \\
\hline SELFSOURCES & $\begin{array}{r}7.326^{* * * *} \\
(2.311)\end{array}$ & & & & \\
\hline Constant & & $\begin{array}{r}-0.508 * * \\
(0.234)\end{array}$ & $\begin{array}{r}-3.060 * * * \\
(0.481)\end{array}$ & $\begin{array}{r}-2.146 * * * \\
(0.435)\end{array}$ & $\begin{array}{r}-1.919 * * * \\
(0.433)\end{array}$ \\
\hline Observations & 14010 & 14010 & 14010 & 14010 & 14010 \\
\hline
\end{tabular}

Robust standard errors in parentheses $* * * p<0.01$, ** $p<0.05$, * $p<0.1$

breakthrough in the Chemistry \& Pharmaceuticals and Mechanical Engineering sectors, whereas it increases the probability of observing an invention in the Electrical Engineering sector. Finally, a breakthrough invention with at least one academic applicant is less likely to occur in the Process Engineering and Mechanical Engineering sectors, whereas it is more likely to occur in the Instruments sector.

Turning our attention to the impact of alternative-specific covariates, SCHUMP, which is our main variable of interest, has a negative and significant marginal effect. This result suggests that breakthrough inventions are more likely to occur in sectors characterized by a Schumpeter Mark I type of innovation patterns than in Schumpeter Mark II. This result appears both in Tables 6 and 7. This finding is of particular interest also because it is likely that our measure of breakthrough invention will probably be biased towards inventions emerging from the corporate $\mathrm{R} \& \mathrm{D}$ segment of the economy.

Interestingly enough, concerning the variety of knowledge source across firms indicator (HERFSOURCES_FIRM), we find that the more the amount of relevant knowledge in a sector is concentrated across firms, the lower is 
Table 7 Conditional Multinomial Logit regressions-marginal effects

\begin{tabular}{|c|c|c|c|c|c|}
\hline Variables & $\begin{array}{l}\text { (1) } \\
\text { Electrical } \\
\text { eng. }\end{array}$ & $\begin{array}{l}\text { (2) } \\
\text { Instruments }\end{array}$ & $\begin{array}{l}\text { (3) } \\
\text { Chemistry } \\
\text { pharma }\end{array}$ & $\begin{array}{l}\text { (4) } \\
\text { Process } \\
\text { eng. }\end{array}$ & $\begin{array}{l}\text { (5) } \\
\text { Mechanical } \\
\text { eng. }\end{array}$ \\
\hline $\operatorname{Pr}($ OST $5=\mathrm{j} \mid 1$ selected $)$ & 0.264 & 0.372 & 0.056 & 0.221 & 0.087 \\
\hline MAPPL & $\begin{array}{l}0.008 \\
\quad(0.021)\end{array}$ & $\begin{array}{r}-0.073 * * * \\
(0.023)\end{array}$ & $\begin{array}{r}-0.017 \\
(0.010)\end{array}$ & $\begin{array}{l}0.017 \\
\quad(0.020)\end{array}$ & $\begin{array}{r}0.065^{* * * *} \\
(0.016)\end{array}$ \\
\hline NINV & $\begin{array}{r}-0.018^{*} \\
(0.010)\end{array}$ & $\begin{array}{l}0.001 \\
\quad(0.011)\end{array}$ & $\begin{array}{l}0.007 \\
(0.004)\end{array}$ & $\begin{array}{l}0.014 \\
\quad(0.009)\end{array}$ & $\begin{array}{r}-0.003 \\
(0.006)\end{array}$ \\
\hline USA & $\begin{array}{r}-0.110 * * * \\
(0.029)\end{array}$ & $\begin{array}{l}0.006 \\
(0.029)\end{array}$ & $\begin{array}{r}0.025^{* *} \\
(0.010)\end{array}$ & $\begin{array}{r}0.089 * * * \\
(0.022)\end{array}$ & $\begin{array}{r}-0.010 \\
(0.017)\end{array}$ \\
\hline GOV & $\begin{array}{r}0.033 * \\
(0.020)\end{array}$ & $\begin{array}{r}-0.001 \\
\quad(0.022)\end{array}$ & $\begin{array}{r}-0.023 * * \\
(0.009)\end{array}$ & $\begin{array}{l}0.014 \\
(0.018)\end{array}$ & $\begin{array}{r}-0.022 * \\
(0.011)\end{array}$ \\
\hline ACAD & $\begin{array}{r}-0.026 \\
(0.034)\end{array}$ & $\begin{array}{r}0.167 * * * \\
(0.039)\end{array}$ & $\begin{array}{l}0.013 \\
(0.019)\end{array}$ & $\begin{array}{r}-0.098 * * * \\
(0.024)\end{array}$ & $\begin{array}{r}-0.057 * * * \\
(0.012)\end{array}$ \\
\hline dum1986_1995 & $\begin{array}{l}0.009 \\
(0.026)\end{array}$ & $\begin{array}{r}-0.025 \\
(0.027)\end{array}$ & $\begin{array}{r}-0.029 * * * \\
(0.010)\end{array}$ & $\begin{array}{r}0.052 * * \\
(0.022)\end{array}$ & $\begin{array}{r}-0.007 \\
(0.017)\end{array}$ \\
\hline dum1996_2005 & $\begin{array}{l}0.045 \\
\quad(0.028)\end{array}$ & $\begin{array}{r}-0.089 * * * \\
(0.027)\end{array}$ & $\begin{array}{l}0.031^{*} \\
\quad(0.018)\end{array}$ & $\begin{array}{l}0.029 \\
\quad(0.026)\end{array}$ & $\begin{array}{r}-0.015 \\
\quad(0.017)\end{array}$ \\
\hline PAT_GROWTH & $\begin{array}{l}0.117 \\
(0.099)\end{array}$ & $\begin{array}{l}0.141 \\
\quad(0.119)\end{array}$ & $\begin{array}{l}0.032 \\
\quad(0.027)\end{array}$ & $\begin{array}{l}0.104 \\
(0.088)\end{array}$ & $\begin{array}{l}0.048 \\
(0.041)\end{array}$ \\
\hline SCHUMP & $\begin{array}{r}-0.093 * * * \\
(0.035)\end{array}$ & $\begin{array}{r}-0.112 * * * \\
(0.042)\end{array}$ & $\begin{array}{r}-0.025^{* * * *} \\
(0.010)\end{array}$ & $\begin{array}{r}-0.083 * * * \\
(0.031)\end{array}$ & $\begin{array}{r}-0.038 * * * \\
(0.014)\end{array}$ \\
\hline HERFSOURCES_TECH & $\begin{array}{r}-0.131 \\
\quad(0.210)\end{array}$ & $\begin{array}{r}-0.158 \\
\quad(0.253)\end{array}$ & $\begin{array}{r}-0.036 \\
(0.057)\end{array}$ & $\begin{array}{r}-0.116 \\
\quad(0.533)\end{array}$ & $\begin{array}{r}-0.054 \\
\quad(0.086)\end{array}$ \\
\hline HERFSOURCES_FIRM & $\begin{array}{r}-0.215 * * * \\
(0.063)\end{array}$ & $\begin{array}{r}-0.258^{* * *} \\
(0.076)\end{array}$ & $\begin{array}{r}-0.059 * * * \\
(0.001)\end{array}$ & $\begin{array}{r}-0.190 * * * \\
(0.056)\end{array}$ & $\begin{array}{r}-0.088 * * * \\
(0.026)\end{array}$ \\
\hline SELFSOURCES & $\begin{array}{r}1.423 * * * \\
(0.449)\end{array}$ & $\begin{array}{r}1.712 * * * * \\
(0.541)\end{array}$ & $\begin{array}{r}0.388 * * * \\
(0.125)\end{array}$ & $\begin{array}{r}1.261 * * * \\
(0.399)\end{array}$ & $\begin{array}{r}0.582 * * * \\
(0.187)\end{array}$ \\
\hline Observations & 14010 & 14010 & 14010 & 14010 & 14010 \\
\hline
\end{tabular}

Robust standard errors in parentheses $* * * p<0.01, * * p<0.05, * p<0.1$

the probability of observing a breakthrough invention in that sector. At the same time, however, the probability of observing a breakthrough increases with the degree of knowledge 'cumulativeness' in a given sector as captured by the relative degree at which each firm exploits its internal source of knowledge (SELFSOURCES).

\subsection{Robustness checks and sensitivity analysis}

The CML model estimated above relies on the Independence of Irrelevant Alternatives (IIA) assumption which states that the relative odds between two alternatives considered (e.g. the probability of awarding an invention in the Instruments vs. Electrical Engineering macro-sectors) is not affected by adding another alternative (e.g. by adding another macro-sector not considered in our analysis) or by changing the characteristics of a third alternative (e.g. by splitting in two the Chemistry \& Pharmaceutical macro-sectors). Although this assumption seems plausible in our setting, since we have classified expost the awarded inventions in the OST sectors with respect to the decision 
of the awarding board, ${ }^{10}$ we report in this sub-section (as a robustness check exercise) the estimates of an alternative econometric model which relaxes the IIA assumption. The Alternative-Specific Multinomial Probit (ASMNP) regression model (Drukker and Gates 2006) assumes a multinomial distribution for the error terms $\varepsilon_{i j}$ in each $\mathrm{j}$-alternative latent variable equation $p r_{i j}^{*}$ with a user-specified correlation structure $\Omega$ :

$$
\begin{aligned}
p r_{i j}^{*} & =X_{i j} \beta+Z_{i} \gamma_{i}+\varepsilon_{i j} \text { and } \\
\underline{\varepsilon}_{j}^{\prime} & =\left(\varepsilon_{i 1}, \ldots, \varepsilon_{i J}\right) \sim \operatorname{MVN}(0, \Omega), \text { for } j=1, \ldots, \mathrm{J} \text { and } \mathrm{i}=1, \ldots, \mathrm{N} .
\end{aligned}
$$

The simulated maximum likelihood estimator for the ASMNP is computed using the command asmprobit on STATA 11-SE version which implements the GHK algorithm (Geweke 1989; Hajivassiliou and McFadden 1998; Keane and Wolpin 1994) to approximate the multivariate distribution function. Tables 8 and 9 report respectively the estimated coefficients and marginal effects of the ASMNP model. ${ }^{11}$ In most of the cases, the sign, the statistical significance and the magnitude of the estimates are similar to the CML estimates.

Moreover, for those sectors in which the alternative-specific regressors have the most significant estimated impact (Instruments, Chemistry \& Pharmaceuticals, and Mechanical Engineering), Fig. 7 shows the degree of sensitivity of the marginal effects with respect to different levels of the alternative specific regressors considered in different sectors.

Interestingly enough, the estimated impact of the Schumpeterian regime indicator (SCHUMP), although being always negative, shows a different behavior with respect to the sector considered. In the sector Instruments, the estimated negative marginal effect tends to become stronger the more the Schumpeterian regime gets closer to a Mark II type, whereas in Mechanical Engineering, the negative impact tends to become weaker. For Chemistry \& Pharmaceuticals, although on average the estimated marginal effect of SCHUMP is negative, we observe a U-shaped pattern with a rate of change in the simulated probability of getting an invention awarded which decreases (i.e. the estimated negative impact becomes stronger) when moving from an highly 'turbulent' Schumpeterian Mark I type to an 'intermediate' type, and then increases when moving from an 'intermediate' type to an highly 'stable' Mark II type regime.

A similar non-monotonic pattern is found when considering the effect of HERFSOURCES_FIRM in the Instruments sector. The rate of change in the simulated probability of observing a breakthrough invention in this sector decreases when moving from a low concentrated (in terms of relevant knowledge

\footnotetext{
${ }^{10}$ As we already mentioned, the R\&D 100 awarding board was not faced with a real choice amongst macro-sectors alternatives when deciding which invention deserved the prize (i.e. there were no 'pre-determined' shares of awards reserved for each sector).

${ }^{11}$ The marginal effects are computed considering the mean value for continuous variables and a discrete change $0-1$ for binary variables.
} 
Table 8 Alternative Specific Multinomial Probit regression

\begin{tabular}{|c|c|c|c|c|c|}
\hline Variables & $\begin{array}{l}\text { (1) } \\
\text { All } \\
\text { sectors }\end{array}$ & $\begin{array}{l}\text { (2) } \\
\text { Instruments }\end{array}$ & $\begin{array}{l}\text { (3) } \\
\text { Chemistry } \\
\text { pharma }\end{array}$ & $\begin{array}{l}\text { (4) } \\
\text { Process } \\
\text { eng. }\end{array}$ & $\begin{array}{l}(5) \\
\text { Mechanical } \\
\text { eng. }\end{array}$ \\
\hline MAPPL & & $\begin{array}{r}-0.134 * * * \\
(0.0375)\end{array}$ & $\begin{array}{r}-0.142 * * * \\
(0.0368)\end{array}$ & $\begin{array}{l}0.871 \\
(1.231)\end{array}$ & $\begin{array}{c}-0.0289 \\
(0.0271)\end{array}$ \\
\hline NINV & & $\begin{array}{r}0.0820 * * * \\
(0.0183)\end{array}$ & $\begin{array}{r}0.0878 * * * \\
(0.0174)\end{array}$ & $\begin{array}{c}0.980 * * \\
(0.406)\end{array}$ & $\begin{array}{r}0.0590 * * * \\
(0.0141)\end{array}$ \\
\hline USA & & $\begin{array}{r}0.431 * * * \\
(0.0409)\end{array}$ & $\begin{array}{r}0.468 * * * \\
(0.0395)\end{array}$ & $\begin{array}{l}5.941 \\
(3.730)\end{array}$ & $\begin{array}{r}0.329 * * * \\
(0.0289)\end{array}$ \\
\hline GOV & & $\begin{array}{r}-0.148 * * * \\
(0.0385)\end{array}$ & $\begin{array}{r}-0.161 * * * \\
(0.0362)\end{array}$ & $\begin{array}{r}0.721 \\
(1.004)\end{array}$ & $\begin{array}{r}-0.131 * * * \\
(0.0295)\end{array}$ \\
\hline ACAD & & $\begin{array}{l}0.211 \\
(0.157)\end{array}$ & $\begin{array}{l}0.206 \\
(0.162)\end{array}$ & $\begin{array}{r}-6.023 * * \\
(2.661)\end{array}$ & $\begin{array}{l}0.0583 \\
(0.127)\end{array}$ \\
\hline dum1986_1995 & & $\begin{array}{l}0.0403 \\
(0.0443)\end{array}$ & $\begin{array}{l}0.0669 \\
(0.0422)\end{array}$ & $\begin{array}{r}3.687 * * * \\
(1.152)\end{array}$ & $\begin{array}{l}0.0177 \\
(0.0351)\end{array}$ \\
\hline dum1996_2005 & & $\begin{array}{r}-0.133^{* * *} * \\
(0.0435)\end{array}$ & $\begin{array}{c}-0.0753^{*} \\
(0.0416)\end{array}$ & $\begin{array}{r}3.857 * * * \\
(1.177)\end{array}$ & $\begin{array}{r}-0.145^{* * *} \\
(0.0336)\end{array}$ \\
\hline PAT_GROWTH & $\begin{array}{r}0.0905 * * * \\
(0.0231)\end{array}$ & & & & \\
\hline SCHUMP & $\begin{array}{r}-0.0971^{* * *} \\
(0.00389)\end{array}$ & & & & \\
\hline HERFSOURCES_TECH & $\begin{array}{r}-0.151 * * * \\
(0.0177)\end{array}$ & & & & \\
\hline HERFSOURCES_FIRM & $\begin{array}{r}-0.249 * * * \\
(0.00691)\end{array}$ & & & & \\
\hline SELFSOURCES & $\begin{array}{c}0.712 * * * \\
(0.0962)\end{array}$ & & & & \\
\hline Constant & & $\begin{array}{r}0.162 * * * \\
(0.0612)\end{array}$ & $\begin{array}{l}0.0459 \\
(0.0656)\end{array}$ & $\begin{array}{r}-2.03 * * * \\
(0.1109)\end{array}$ & $\begin{array}{c}0.171 * * * \\
(0.0470)\end{array}$ \\
\hline Observations & 14010 & 14010 & 14010 & 14010 & 14010 \\
\hline
\end{tabular}

Robust standard errors in parentheses *** $p<0.01$, ** $p<0.05$, * $p<0.1$

Table 9 Alternative Specific Multinomial Probit regression-marginal effects (alternative specific regressors)

\begin{tabular}{|c|c|c|c|c|c|}
\hline Variables & $\begin{array}{l}\text { (1) } \\
\text { Electrical } \\
\text { eng. }\end{array}$ & $\begin{array}{l}\text { (2) } \\
\text { Instruments }\end{array}$ & $\begin{array}{l}\text { (3) } \\
\text { Chemistry } \\
\text { pharma }\end{array}$ & $\begin{array}{l}(4) \\
\text { Process } \\
\text { eng. }\end{array}$ & $\begin{array}{l}(5) \\
\text { Mechanical } \\
\text { eng. }\end{array}$ \\
\hline $\operatorname{Pr}($ OST $5=\mathrm{j} \mid 1$ selected $)$ & 0.258 & 0.378 & 0.055 & 0.218 & 0.086 \\
\hline PAT_GROWTH & $\begin{array}{r}0.0015 \\
(0.001)\end{array}$ & $\begin{array}{r}0.192 * * \\
(0.080)\end{array}$ & $\begin{array}{r}0.123 * * * \\
(0.046)\end{array}$ & $\begin{array}{l}0.0005 \\
(0.001)\end{array}$ & $\begin{array}{l}0.076^{*} \\
(0.044)\end{array}$ \\
\hline SCHUMP & $\begin{array}{c}-0.0014 * \\
(0.0008)\end{array}$ & $\begin{array}{r}-0.190 * * * \\
(0.041)\end{array}$ & $\begin{array}{r}-0.121 * * * \\
(0.027)\end{array}$ & $\begin{array}{r}-0.0005 \\
(0.001)\end{array}$ & $\begin{array}{r}-0.075^{* *} \\
(0.030)\end{array}$ \\
\hline HERFSOURCES_TECH & $\begin{array}{r}-0.003 \\
(0.002)\end{array}$ & $\begin{array}{r}-0.355^{*} \\
(0.209)\end{array}$ & $\begin{array}{r}-0.227 * \\
(0.091)\end{array}$ & $\begin{array}{r}-0.001 \\
\quad(0.005)\end{array}$ & $\begin{array}{r}-0.140 \\
\quad(0.097)\end{array}$ \\
\hline HERFSOURCES_FIRM & $\begin{array}{r}-0.004 * * \\
(0.002)\end{array}$ & $\begin{array}{r}-0.472 * * * \\
(0.078)\end{array}$ & $\begin{array}{r}-0.301 * * * \\
(0.075)\end{array}$ & $\begin{array}{r}-0.001 \\
\quad(0.005)\end{array}$ & $\begin{array}{r}-0.186 * * * \\
(0.026)\end{array}$ \\
\hline SELFSOURCES & $\begin{array}{r}0.011^{*} \\
(0.006)\end{array}$ & $\begin{array}{r}1.473 * * * \\
(0.360)\end{array}$ & $\begin{array}{r}0.939 * * * \\
(0.215)\end{array}$ & $\begin{array}{l}0.004 \\
(0.009)\end{array}$ & $\begin{array}{r}0.581 * * \\
(0.258)\end{array}$ \\
\hline Observations & 14010 & 14010 & 14010 & 14010 & 14010 \\
\hline
\end{tabular}

Robust standard errors in parentheses *** $p<0.01$, ** $p<0.05$, * $p<0.1$ 

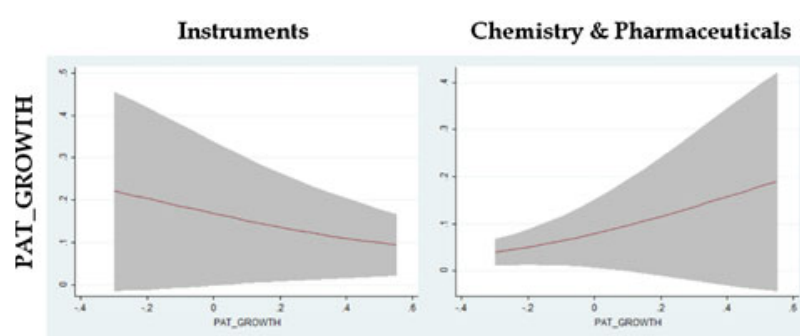

Mechanical Engineering
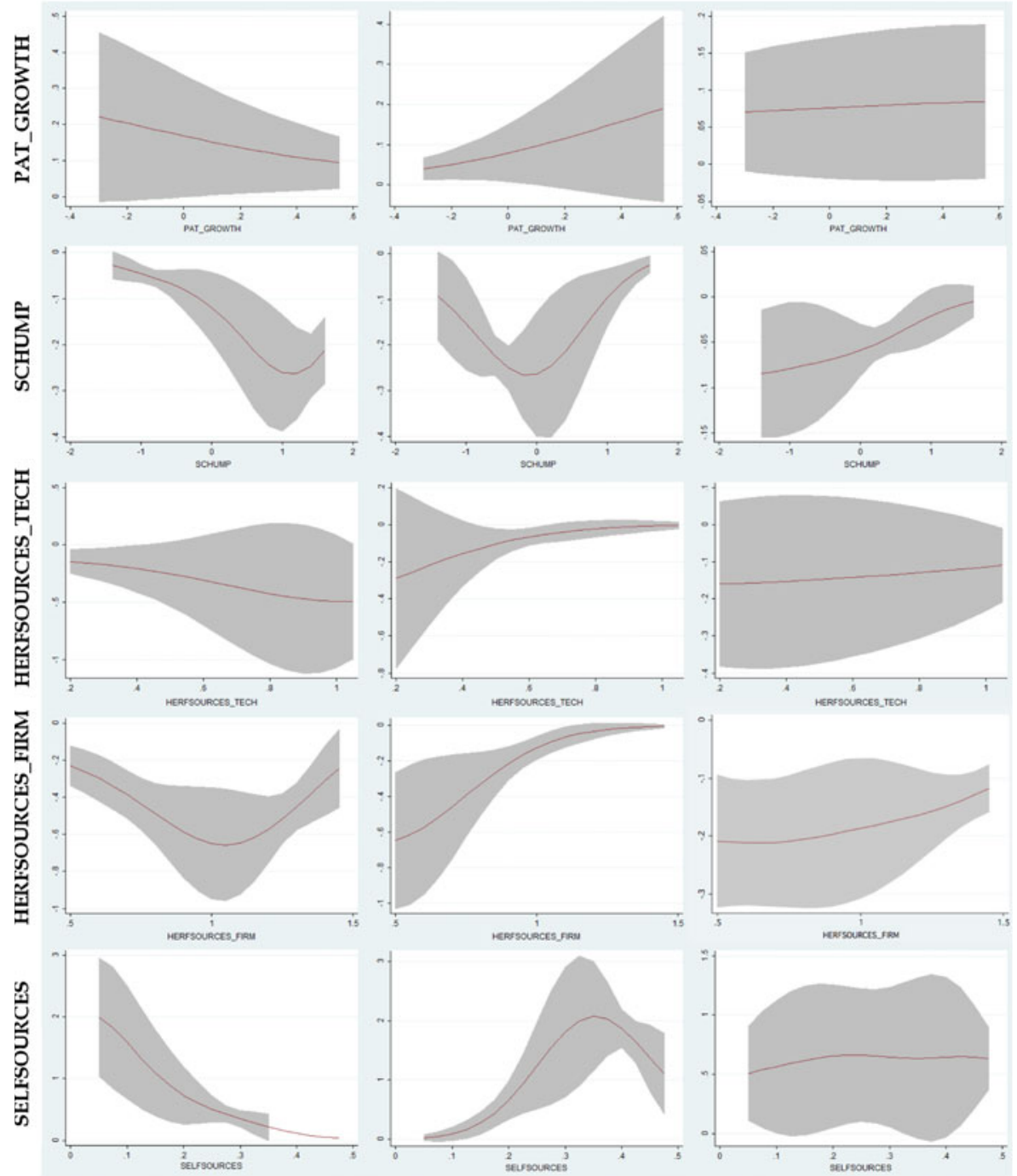

Fig. 7 Estimated marginal effects (red line) for different values of the covariates in different sectors $(95 \%$ confidence interval is the grey area)

owned by firms) to an 'average' concentrated scenario, and then increases when moving to an highly concentrated one. In the other two sectors considered (Chemistry \& Pharmaceuticals and Mechanical Engineering), the estimated negative marginal effects monotonically decreases with the degree of concentration. Finally, concerning the estimated positive impact of the relevance of the internal sources of knowledge (SELFSOURCES), we can see that its intensity tends to decrease with the degree of knowledge 
'cumulativeness' in the Instruments sector whereas the pattern is invertedU-shaped for the Chemistry \& Pharmaceuticals sector and constant for the Mechanical Engineering sector.

\section{Concluding remarks}

Economists of innovation have been aware for a long time that patterns of innovative activities differ across industries. So far, most research efforts have been devoted to the construction of taxonomies that could be fruitfully employed to interpret the variety of sectoral innovation patterns. In this respect, the Schumpeter Mark I/ Schumpeter Mark II distinction has been, together with the Pavitt (1984) taxonomy, the interpretative approach that has gained the widest currency. In fact, the characterization of sectoral patterns of innovation in terms of the Schumpeter Mark I/ Schumpeter Mark II distinction has consistently emerged in different countries using different type of data to measure innovative activities (e.g., USPTO patents, EPO patents and national Innovation Surveys responses).

In this paper, we have expanded on this line of research by examining the relationship between different sectoral patterns of innovation (characterized in terms of technological regimes and Schumpeter Mark I/ Schumpeter Mark II patterns) and the generation of breakthrough inventions. To address this issue, we have used two different sources of data. We have used USPTO patents to capture the relevant dimensions of the technological regime prevailing in each sector and to construct an indicator of the degree in which each sector can be identified as either a Schumpeter Mark I or Schumpeter Mark II. We have used a new data set of awarded inventions to measure the number of breakthrough inventions generated by each sectors. Our findings indicate that, in general, a Schumpeter Mark I 'turbulent' environment rather than a more 'stable' Schumpeter Mark II is conducive to a higher probability of the occurrence of breakthrough inventions.

Though preliminary and in need of further corroboration, we think that our results bear some important implications for the existing literature on innovation. First, they extend the analysis of the relationship between Schumpeterian pattern of innovation and economic performance to the case of breakthrough inventions. In this respect, our findings appear somewhat consistent with those of Castellacci (2007) on the relationship between productivity growth and sectoral patterns of innovation. Also in that case he found that the relationship between productivity growth and the dimensions of the technological regime was articulated in a different way in Schumpeter Mark I and Schumpeter Mark II patterns. Second, our results complement the evidence provided by recent studies in the management tradition that look at the sources of innovative breakthroughs mainly at the individual level. While the probability of achieving a breakthrough may be related to inventors' past experience and ability (Conti et al. 2010) and/or to the organizational setting in which the research activity takes place (Jeppesen and Lakhani 2010), industry characteristics seem 
also to play an important role and ought to be considered when carrying out firm level studies. Finally, our results bear also some policy implications. If an entrepreneurial regime is an environment relatively more conducive to breakthrough inventions, then it is clear that intelligent innovation policies would better follow the advice of Jewkes et al. (1958) and pay attention to the role of small firms and/or individual entrepreneurs rather than focusing exclusively inside the walls of the research and development facilities of large corporations.

Acknowledgements We thank the editors of the special issue and an anonymous reviewer for helpful suggestions. We have also benefited from comments of seminar participants at the International Schumpeter Society Conference 2010, Workshop on 'Knowledge Integration and Innovation', EPIP conference 2009, EMAEE Conference 2009. Fontana and Nuvolari acknowledge financial support from European Union, project FP6 - 043345, NEST-2005-Path-CUL: "CID-Cultural Innovation Dynamics. Explaining the uneven evolution of human knowledge".

\section{References}

Ahuia G, Lampert C (2001) Entrepreneurship in the large corporation: a longitudinal study of how established firms create breakthrough inventions. Strateg Manag J 22:521-543

Block F, Keller M (2009) Where do innovations come from? Transformations in the US economy. Socio-Econ Rev 7:459-483

Breschi S, Malerba F, Orsenigo L (2000) Technological regimes and schumpeterian patterns of innovation. Econ J 110:388-410

Carpenter MP, Narin F, Woolf P (1981) Citation rates to technologically important patents. World Pat Inf 3:160-163

Castellacci F (2007) Technological regimes and sectoral differences in productivity growth. Ind Corp Change 16:1105-1145

Chandy R, Tellis G (2000) The incumbent's curse? Incumbency, size and radical product innovation. J Market 64:1-17

Cohen WM (2010) Fifty years of empirical studies of innovative activity and performance. In: Hall B, Rosenberg N (eds) The handbook of economics of innovation. Elsevier, Amsterdam, pp 129-213

Conti R, Gambardella A, Mariani M (2010) Learning to be Edison? Individual inventive experience and breakthrough inventions. Paper presented at DRUID Academy conference 2010

Corrocher N, Malerba F, Montobbio F (2007) Schumpeterian patterns of innovation in the ICT field. Res Policy 36:418-432

Drukker DM, Gates R (2006) Generating Halton sequences using Mata. Stata J 6:278-294

Freeman C (1991) Networks of innovators. A synthesis of research issues. Res Policy 20:499-514

Geweke J (1989) Bayesian inference in econometric models using Monte Carlo integration. Econometrica 57:1317-1339

Granstrand O, Alange S (1995) The evolution of corporate entrepreneurship in Swedish industry - was Schumpeter wrong? J Evol Econ 5:133-156

Hajivassiliou VA, McFadden DL (1998) The method of simulated scores for the estimation of LDV models. Econometrica 66:863-896

Hall B, Jaffe A, Trajtenberg M (2001) The NBER patent citations data file: lessons, insights, methodological tools. NBER Working Paper n. 849w8

Hinze S, Reiss T, Schmoch U (1997) Statistical analysis on the distance between fields of technology. Report for the European Commission, TSER project

Jeppesen LB, Lakhani KR (2010) Marginality and problem solving effectiveness in broadcast search. Org Sci 21(5):1016-1033

Jewkes J, Sawers D, Stillerman R (1958) The sources of invention. MacMillan, London (rev. edn. 1969) 
Keane MP, Wolpin KI (1994) The solution and estimation of discrete choice dynamic programming models by simulation and intermpolation: Monte Carlo evidence. Rev Econ Stat 76:648672

Khan Z, Sokoloff K (1993) "Schemes of practical utility": entrepreneurship and innovation among "great inventors" in the United States, 1790-1865. J Econ Hist 53:289-307

Malerba F (2005) Sectoral systems: how and why innovation differs across sectors. In: Fagerberg J, Mowery DC, Nelson RR (eds) The Oxford handbook of innovation. Oxford University Press, Oxford, pp 380-406

Malerba F, Orsenigo L (1995) Schumpeterian patterns of innovation. Camb J Econ 19:47-65

Malerba F, Orsenigo L (1996) Schumpeterian patterns of innovation are technology-specific. Res Policy 25:451-478

Malerba F, Orsenigo L (1997) Technological regimes and sectoral patterns of innovative activities. Ind Corp Change 6:83-117

Marsili O, Verspagen B (2002) Technology and the dynamics of industrial structures: an empirical mapping of Dutch manufacturing. Ind Corp Change 11:791-815

Mokyr J (1990) The lever of riches. Oxford University Press, Oxford

Mowery DC, Nelson RR (eds) (1999) Sources of industrial leadership. Cambridge University Press, Cambridge

Nelson RR, Winter S (1982) An evolutionary theory of economic change. Harvard University Press, Cambridge

Pavitt K (1984) Patterns of technical change: towards a taxonomy and a theory. Res Policy 13:343373

Scherer FM (1989) "Comments" on Z. Griliches, "Patents: recent trends and puzzles". Brook Pap Econ Act 9:291-330

Scherer FM, Harhoff D (2000) Technology policy for a world of skewed distributed outcomes. Res Policy 29:559-566

Schoenmakers W, Duysters G (2010) The technological origins of radical inventions. Res Policy 39:1051-1059

Silverberg G, Verspagen B (2007) The size distribution of innovations revisited: an application of extreme value statistics to citation and value measure of patent significance. J Econ 139:318319

Singh J, Fleming L (2010) Lone inventors as sources of breakthroughs: myth or reality? Manag Sci $56: 41-56$

Van Dijk M (2000) Technological regimes and industrial dynamics: the evidence from Dutch manufacturing. Ind Corp Change 9:173-194 